\title{
Effect of Nanoparticles for Seed Quality Enhancement in Onion [Allium cepa (Linn) cv. CO (On)] 5
}

\author{
K. Anandaraj* and N. Natarajan \\ Department of Seed Science and Technology, Tamil Nadu Agricultural University, \\ Coimbatore - 641 003, Tamil Nadu, India \\ *Corresponding author
}

A B S T R A C T

\begin{abstract}
Keywords
Onion, Seed Quality,

Allium cepa, nano

particle, Nano seed

treatment, $\mathrm{ZnO}, \mathrm{Ag}$,

$\mathrm{CuO}$ and $\mathrm{TiO} 2$

Nanoparticles, SEM,

TEM, Particle Size

Analyzer, Raman

Spectroscopy.

Article Info

Accepted:

26 September 2017

Available Online:

10 November 2017

Zinc oxide $(\mathrm{ZnO})$, Silver $(\mathrm{Ag})$, Copper oxide $(\mathrm{CuO})$ and Titanium oxide $\left(\mathrm{TiO}_{2}\right)$ nanoparticles were synthesised using simple chemical route which were characterised using Scanning Electron Microscope (SEM), Transmission Electron Microscope (TEM), Particle Size Analyzer and Raman Spectroscopy. Size of Zinc oxide $(\mathrm{ZnO})$, Silver $(\mathrm{Ag})$ Copper oxide $(\mathrm{CuO})$ and Titanium dioxide $\left(\mathrm{TiO}_{2}\right)$ nanoparticles measured $16-50 \mathrm{~nm}, 50-100 \mathrm{~nm}, 60-150 \mathrm{~nm}$ and $100-120$, respectively to conform the nano-size. Onion seeds when dry dressed with the synthesised nanoparticles each at 750, 1000, 1250 and $1500 \mathrm{mg} \mathrm{kg}^{-1}$, the dose of $1000 \mathrm{mg} \mathrm{kg}^{-1}$ outperformed in enhancing the germination (72\%), shoot length $(7.5 \mathrm{~cm})$ root length (6.4) and thereby the vigour index (998) compared to control $(60 \%, 6.0,5.4$ and 692) respectively.
\end{abstract}

\section{Introduction}

Onion (Allium cepa L.) belongs to the family Liliaceae and is one of the most important monocotyledonous and cool season vegetable crops in India. Amongst the onion producing countries in the World, India ranks second in area and production. Onion has been the largest item of export accounting to 76.2 per cent in the total export of vegetables from India. The unavailability of quality onion seed is greatly responsible for its lower yield. The seed quality parameters especially seed size and seed weight affect the final yield in onion production (Gamiely et al., 1991). Furthermore, high quality seed is considered as the critical input in onion on which all other inputs have to be managed for potential yield in onion. Onion is grown in an area of $1.01 \mathrm{~m}$ ha with a production of $16.8 \mathrm{~m}$ tonnes keeping the productivity at $16.6 \mathrm{t} \mathrm{ha}^{-1}$. The prominent onion growing states are Maharashtra, Gujarat, Uttar Pradesh, Orissa, Karnataka, Tamil Nadu and Andhra Pradesh. Perambalur district in Tamil Nadu has the highest share of production $(24.6 \%)$ followed by Trichy $(14.2 \%)$, Coimbatore $(13.7 \%)$ and Erode $(10.8 \%)$ districts. In India onion seed is getting lost quickly due to the production of free radicals by lipid peroxidation during 
storage. As the current technologies available to prolong the vigour and viability of onion seed on a large scale are not satisfactorily alleviating the practical problem, an alternative simple and practicable seed treatment to control seed deterioration of onion is need of the hour.

Several researchers reported that mid-term hydration-dehydration treatments performed better in improving germinability and seedling vigour after storage in soy bean (Basu 1994; Mandal et al., 2000) and okra (Kapri et al., 2003). Nanoparticles can be one of the ways to retain the vigour and viability during storage by preventing the losses due to biotic and abiotic stress.

Lots of works have been done in biological system to address a wide range of field problems utilizing nanomaterials and nanodevices. (Natarajan and Sivasubramanian, 2008) elucidated various nanotechnological approaches especially in the field of agriculture including nano-polymer for seed hardening, nano-sensors, nano-barcodes and use of magnetic nanoparticles for aerial seeding. (Senthil kumar, 2011) and (Sridhar, 2012) further established the use of metal oxide nano-particles in improving germination up to 30 per cent in aged seeds of black gram and tomato respectively which could be probably due to the quenching of reactive oxygen species (ROS) generated during seed storage. Applications of nanotechnology in improving seed germination, emergence and growth of seedlings (Zhang et al., 2006), thwarting pest attack (Nair et al., 2010) and for early pathogen detection (Alocilja and Radke, 2003) are few of the multifarious beneficial interventions in the field of agriculture. Hence the present investigation was made to study the effect of $\mathrm{ZnO}, \mathrm{Ag}, \mathrm{CuO}$ and $\mathrm{TiO}_{2}$ nanopartilcle on the vigour and viability of onion seed.

\section{Materials and Methods}

The first experiment synthesis of nanoparticles and characterization was carried out at Department of Nano Science and Technology and the second experiment study of seed quality enhancement was carried at Department of Seed Science and Technology, Tamil Nadu Agricultural University, Coimbatore -03 , during the year of 2012-13. The chemicals used for synthesis of nanoparticles viz., Zinc nitrate (Zn $\left.\left(\mathrm{NO}_{3}\right)_{2} \cdot 4 \mathrm{H}_{2} \mathrm{O}\right), \mathrm{AgNO}_{3}$, Trisodium citrate, copper nitrate trihydrate, $\mathrm{TiO}_{2}$ pellets, $\mathrm{NaOH}$ and Ethanol were purchased from THE I.L.E. Co. Pvt. Ltd., Coimbatore, Tamil Nadu.

Synthesis of $\mathrm{ZnO}, \mathrm{Ag}, \mathrm{CuO}$ and $\mathrm{TiO}_{2}$ Nanoparticles

\section{Zinc oxide nanoparticles}

$\mathrm{ZnO}$ NPs were synthesized by adding $0.45 \mathrm{M}$ aqueous solution of zinc nitrate $\left(\mathrm{Zn}\left(\mathrm{NO}_{3}\right)_{2} .4 \mathrm{H}_{2} \mathrm{O}\right)$ and $0.9 \mathrm{M}$ aqueous solution of sodium hydroxide $(\mathrm{NaOH})$ in distilled water taken in two separate $250 \mathrm{ml}$ glass beakers.

The $\mathrm{Zn}\left(\mathrm{NO}_{3}\right)_{2}$ solution $(100 \mathrm{ml})$ transferred to a burette was added drop wise (slowly for 40 min.) to the $100 \mathrm{ml}$ of $\mathrm{NaOH}$ contained in the beaker placed over a magnetic stirrer with hot plate set at $55^{\circ} \mathrm{C}$ with high-speed stirring. The beaker after adding $100 \mathrm{ml} \mathrm{Zn}\left(\mathrm{NO}_{3}\right)_{2}$ was removed from the hot plate, sealed with aluminium foil and kept undisturbed for $2 \mathrm{~h}$ for precipitation and settlement.

The precipitated ZnO NPs were washed with millipore water followed by ethanol and then vacuum dried at $60^{\circ} \mathrm{C}$ (Moghaddam et al., 2009). Nanoparticles such synthesized were transferred to air tight screw cap vial $(10 \mathrm{ml})$ and stored at ambient temperature for further investigations. 


\section{Silver nanoparticles}

The Ag NPs were prepared by using chemical reduction method according to the description outlined by (Lee and Meisel, 2005). Fifty milliliter of $\mathrm{AgNO}_{3} 0.005 \mathrm{M}$ taken in a beaker was boiled on a magnetic stirrer with hot plate. To this solution, $5 \mathrm{ml}$ of $1 \%$ trisodium citrate was added drop by drop from $10 \mathrm{ml}$ measuring cylinder with vigorous mixing on the stirrer until pale yellow colour appeared. Then the beaker was removed and kept at ambient temperature where the chemical reaction occurred would have been

$4 \mathrm{Ag}^{+}+\mathrm{C}_{6} \mathrm{H}_{5} \mathrm{O}_{7} \mathrm{Na}_{3}+2 \mathrm{H}_{2} \mathrm{O} \rightarrow 4 \mathrm{Ag} 0+$ $\mathrm{C}_{6} \mathrm{H}_{5} \mathrm{O}_{7} \mathrm{H}_{3}+3 \mathrm{Na}^{+}+\mathrm{H}^{+}+\mathrm{O}_{2} \uparrow$

\section{Copper oxide Nanoparticles}

$\mathrm{CuO}$ NPs were synthesised using copper nitrate trihydrate $\left(\mathrm{CuN}_{2} \mathrm{O}_{6} .3 \mathrm{H}_{2} \mathrm{O}\right.$, SigmaAldrich), and sodium hydroxide anhydrous pellets $(\mathrm{NaOH}, \mathrm{Carlo}$ erba) in the presence of polyvinyl alcohol (PVA, Sigma Aldrich) as starting precursor (Wongpisutpaisan et al., 2011). Sodium hydroxide was dissolved in deionized water and thus obtained solution $(0.5 \mathrm{M}, 50 \mathrm{ml})$ was added drop wise to an aqueous $\mathrm{CuN}_{2} \mathrm{O}_{6} .3 \mathrm{H}_{2} 0$ solution $(0.1 \mathrm{M}, 50$ $\mathrm{ml}$ ) for $30 \mathrm{~min}$. Sonication of the solution was performed using Sonics Model VCX 1500 until complete precipitation. Finally, precipitated powder was calcined at $600^{\circ} \mathrm{C}$ for $2 \mathrm{~h}$ to obtain the nanoparticles.

\section{Titatium oxide nanoparticles}

$\mathrm{TiO}_{2}$ NPs were synthesized by dissolving 0.5 $\mathrm{g} \mathrm{TiO}_{2}$ pellets in $30 \mathrm{ml}$ of $\mathrm{NaOH}$ solution (10 $\mathrm{M})$ under vigorous stirring at room temperature for $2 \mathrm{~h}$. Thus obtained yellow solution was irradiated in an ultra sonicator (Soncis, VCX 1500, $20 \mathrm{kHz}$ and $350 \mathrm{~W}$ ) for $2 \mathrm{~h}$ in ambient temperature. The resultant precipitate was then centrifuged, washed and decanted with deionized water several times and dried at $60^{\circ} \mathrm{C}$ for $24 \mathrm{~h}$ to obtain the nanoparticles (Arami et al., 2007).

\section{Characterization of synthesized nanoparticles}

Characterization of the synthesized nanoparticles was performed by using Scanning Electron Microscope (SEM), Transmission Electron Microscope (TEM), Particle Size Analyzer and Raman Spectroscopy.

\section{Scanning Electron Microscope (SEM)}

FEI QUANTA 250 was used to characterize the size and morphology of the nanoparticles. Sample of test nanoparticles ( 0.5 to $1.0 \mathrm{mg}$ ) was dusted on one side of the double sided adhesive carbon conducting tape, and then mounted on the $8 \mathrm{~mm}$ diameter aluminum stub. Sample surface were observed at different magnification and the images were recorded.

\section{Transmission Electron Microscope (TEM)}

FEI TECHNAI SPRIT make was used to analyze the sample. Dilute suspensions of NPs $(0.50 \mathrm{mg})$ in pure ethanol $(15 \mathrm{ml})$ were prepared by ultrasonication. A drop of the suspension placed on 300-mesh lacy carbon coated copper grid upon drying, was examined and the images were recorded at different magnification.

\section{Particle size analyzer}

The particle size analyzer was used to determine the particle size and the distribution pattern of synthesized $\mathrm{ZnO}, \mathrm{Ag}, \mathrm{CuO}$ and $\mathrm{TiO}_{2}$ nanoparticles. The particle size distribution (PSD) of a powder indicates a list of values or a mathematical function that defines the relative amount of particles 
present, sorted according to size. In the present study, HORIBA nanoparticle size analyser SZ 100 was used. Accurately, $0.5 \mathrm{mg}$ of sample was dispersed in $10 \mathrm{ml}$ pure water through ultrasonication and the measurements were taken.

\section{Raman spectroscopy}

Raman spectroscopy is a spectroscopic technique based on inelastic scattering of monochromatic light, usually from a laser source. Inelastic scattering means that the frequency of photons in monochromatic light changes upon interaction with the sample. Photons of the laser light are absorbed by the sample and then reemitted. Frequency of the reemitted photons can be shifted either up or down in comparison to the original monochromatic frequency which is called the Raman Effect. This shift provides information about vibrational, rotational and other low frequency transitions happening in the molecules. Raman spectroscopy can be used to study solid, liquid and gaseous samples.

Raman spectrum is a spectral "fingerprint". If number of different compounds is present in a mixture, the resulting Raman spectra will be a superposition of the spectrum of each of the components. The relative intensities of the peaks can be used to give quantitative information on the composition of mixture of known compounds. The Raman spectrum was measured for the synthesized nanoparticles using Raman spectrum Model- R- 3000- QE. The powdered, dried NPs kept in a polythene bag were spread to an extent of $1 \mathrm{~cm}^{2}$ and Raman probe was placed on the sample packets without exposing the sample directly to the probe (Fig. 2).

\section{Seed treatment}

Fresh seeds of onion (CO 5) obtained from the Department of Vegetable Crops, Horticultural College and Research Institute,
Coimbatore were dry dressed with each of the synthesized nanoparticles viz., $\mathrm{ZnO}, \mathrm{Ag}, \mathrm{CuO}$ and $\mathrm{Tio}_{2} @$ 750,1000,1250, and $1500 \mathrm{mg}$ $\mathrm{kg}^{-1}$ in screw capped glass bottles at room temperature. The glass bottles containing seeds and nanoparticles were manually shaken gently for 3 min., 5 times in a span of 3h. Seeds shaken without nanoparticles served as control. After dry dressing with the nanoparticles, the seeds were packed in cloth bag and stored under ambient condition (25 \pm $3^{0} \mathrm{C}$ temperature and $95 \pm 3 \% \mathrm{RH}$ ).

Seed samples were drawn at monthly intervals up to six months and evaluated for the following seed quality parameters. viz., germination percentage, shoot length, root length, and vigour index.

Germination test in quadruplicate using 100 seeds each with four replicates of 25 seeds was carried out in paper medium. The test conditions of $25 \pm 2{ }^{0} \mathrm{C}$ and $95 \pm$ 3 per cent $\mathrm{RH}$ were maintained in the germination room. At the end of 14 days, the number of normal seedlings was counted and the mean was expressed as percentage (ISTA, 2005).

Root length of all the normal seedlings from the germination test was measured from collar region to the root tip and the mean was expressed in centimetre. Shoot length of all the normal seedlings from the germination test was measured from collar region to the shoot apex and the mean was expressed in centimetre.

Vigour index was computed by adopting the method suggested by (Abdul-Baki and Anderson, 1973) and expressed as whole number.

Vigour index $=$ Germination percentage $\times$ Seedling length in $\mathrm{cm}$. 


\section{Results and Discussion}

Characterization of nanoparticles $(\mathrm{ZnO}$, $\mathrm{Ag}, \mathrm{CuO}$ and $\mathrm{TiO}_{2}$ )

The surface morphology of Zinc Oxide $(\mathrm{ZnO})$, Silver (Ag), Copper Oxide $(\mathrm{CuO})$, and Titanium Oxide $\left(\mathrm{TiO}_{2}\right)$ nanoparticles were examined under SEM, TEM, Particle Size Analyzer and Raman Spectroscopy. The morphology of different nanoparticles observed are presented below.

The particle size analyzer was used to analyze the size of the particle using laser scattering principle for estimating the average particle size and distribution pattern for synthesized $\mathrm{ZnO}, \mathrm{Ag}, \mathrm{CuO}$, and $\mathrm{TiO}_{2}$ nanoparticles. The particle size distribution of $\mathrm{ZnO}, \mathrm{Ag}, \mathrm{CuO}$ and $\mathrm{TiO}_{2}$ was found to be $16,53.7 \mathrm{~nm}, 183$ $\mathrm{nm}$ and $387 \mathrm{~nm}$ respectively (Fig. 1).

Raman spectroscopy was employed to identify the chemical composition and to confirm the four different nanoparticles synthesized by observing the peaks. The peaks were observed at $308,908,1152$ and $1280 \mathrm{~cm}^{-1}$ for $\mathrm{CuO}$ while at $528,871,945$ and $1411 \mathrm{~cm}^{-1}$ for $\mathrm{Ag}, 276,637,1327$ and 1458 $\mathrm{cm}^{-1}$ for $\mathrm{TiO}_{2}$ and 366, 723, 1066 and 1219 $\mathrm{cm}^{-1}$ for $\mathrm{ZnO}$ nanoparticle confirming the respective chemical compounds (Fig. 2).

\section{Seed germination and seedling vigour}

Nanoparticles of $\mathrm{ZnO}, \mathrm{Ag}, \mathrm{CuO}$ and $\mathrm{TiO}_{2}$ when treated in different concentrations viz., 750, 1000, 1250 and $1500 \mathrm{mg} \mathrm{kg}^{-1}$ had significantly outperformed control in terms of germination, shoot length, root length and vigour index. Significant differences were also observed between the nanoparticles and doses.

Nano seed treatment improved the germination of aged onion seeds variably towards the treatment at different concentrations.

Fig.1 Particle analyzer average size and intestity distribution of $\mathrm{ZnO}$ nanoparticles

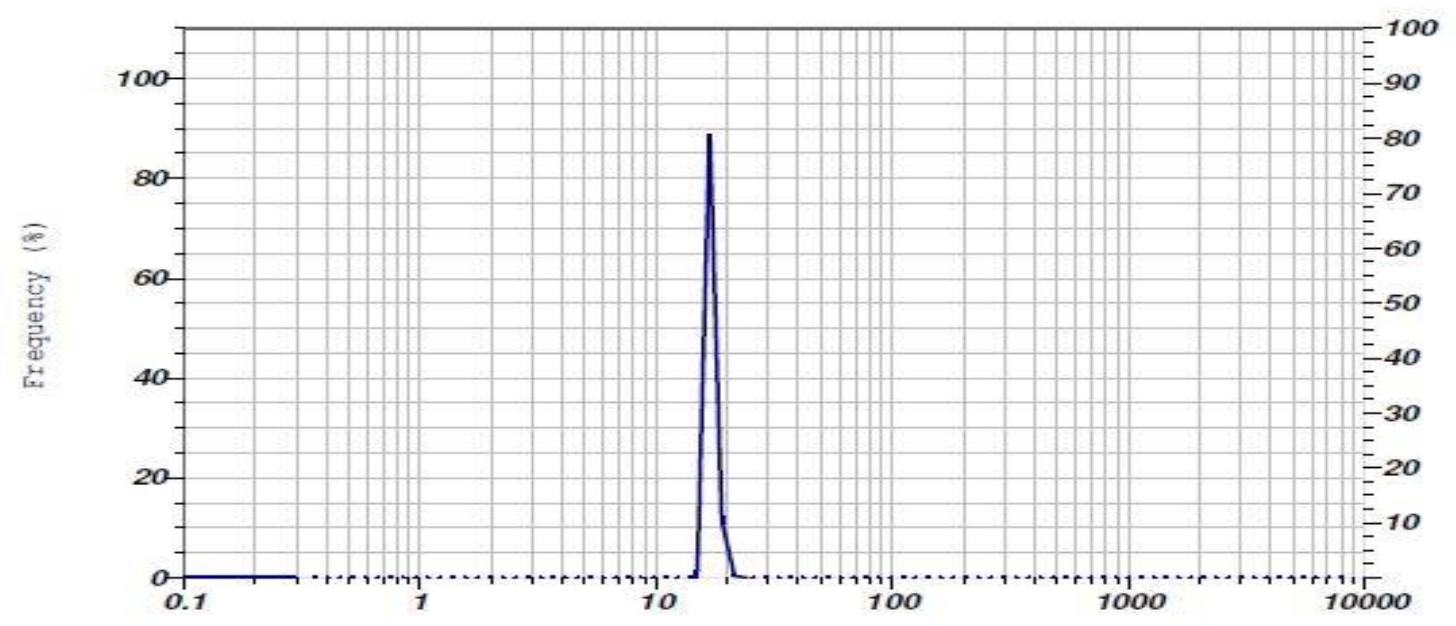

Diameter $(\mathrm{nm})$

\begin{tabular}{|l|l|l|l|l|}
\hline Peak No & S.P. Area Ratio & Mean & S.D & Mode \\
\hline 1 & 1.00 & $16.1 \mathrm{~nm}$ & $0.7 \mathrm{~nm}$ & $16.0 \mathrm{~nm}$ \\
\hline 2 & --- & $---\mathrm{nm}$ & $---\mathrm{nm}$ & $---\mathrm{nm}$ \\
\hline 3 & --- & $--\mathrm{nm}$ & $---\mathrm{nm}$ & $--\mathrm{nm}$ \\
\hline Total & 1.00 & $16.1 \mathrm{~nm}$ & $0.7 \mathrm{~nm}$ & $16.0 \mathrm{~nm}$ \\
\hline
\end{tabular}


Fig.2 Raman spectra of (a) $\mathrm{Zno}$, (b) $\mathrm{Ag}$, (c) $\mathrm{CuO}$ and (d) $\mathrm{TiO}_{2}$ nanoparticles

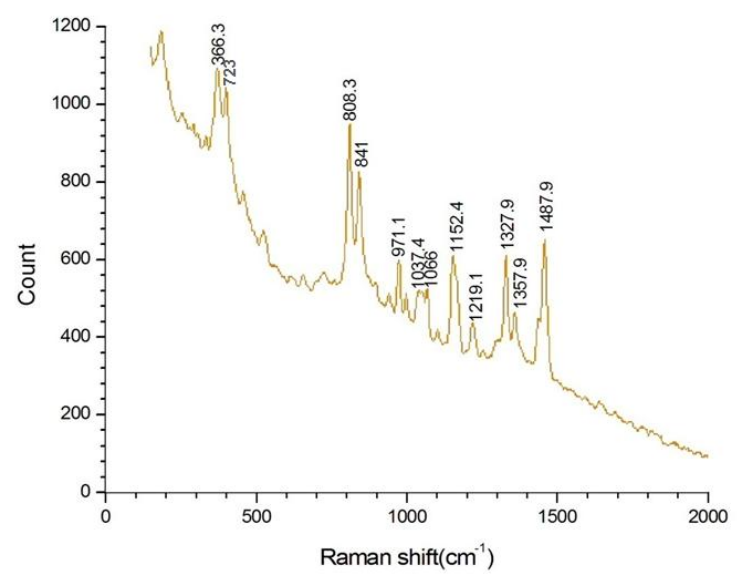

(a)

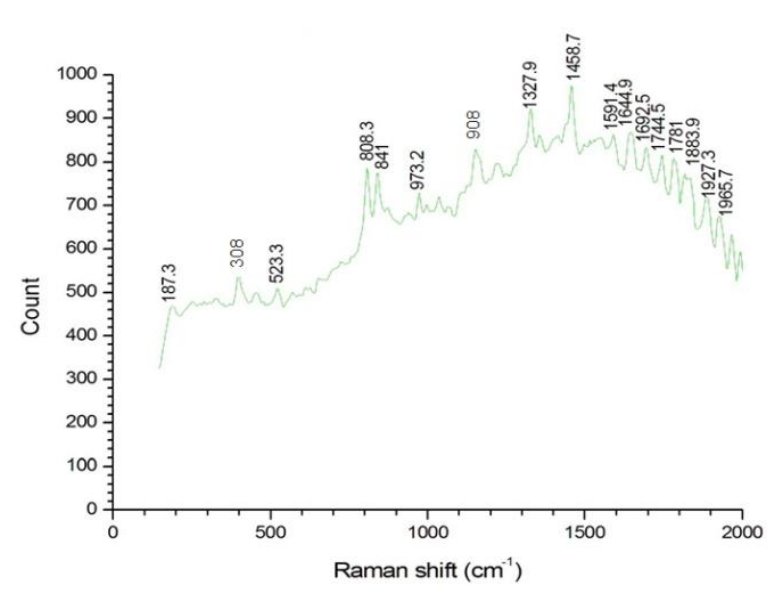

(c)

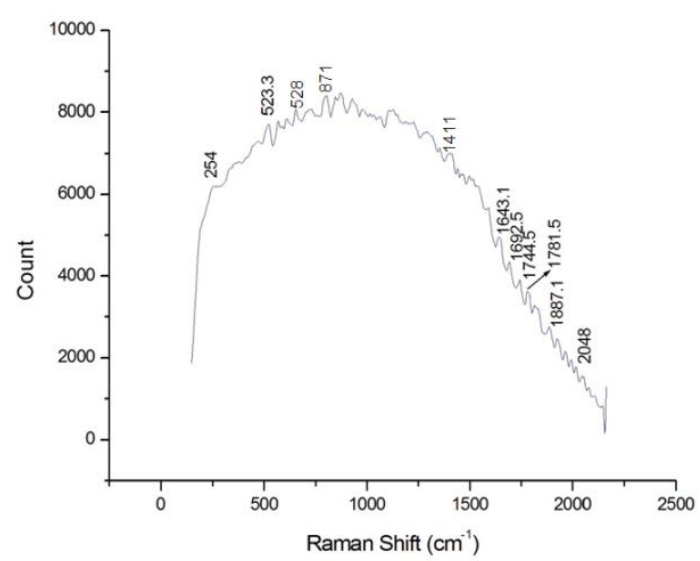

(b)

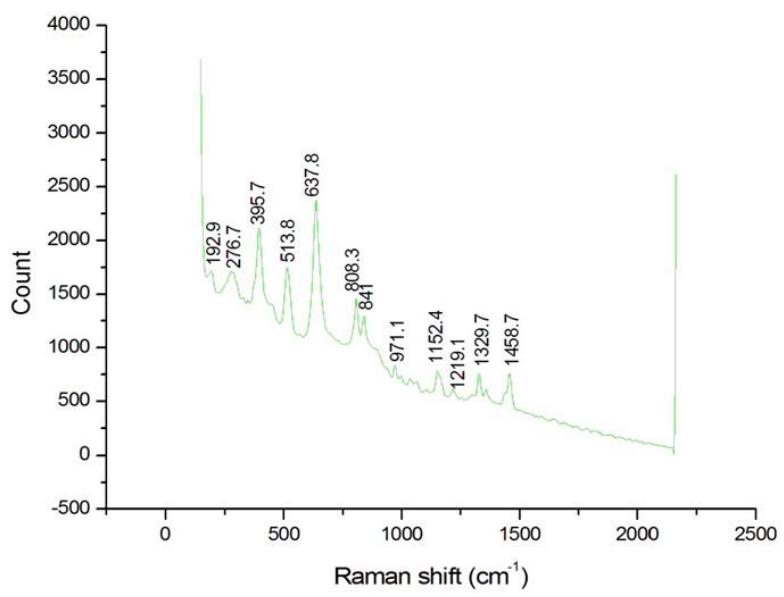

(d)

Plate.1 SEM images of (a) Zno, (b) silver, (c) $\mathrm{CuO}$ and (d) $\mathrm{TiO}_{2}$ nanoparticles

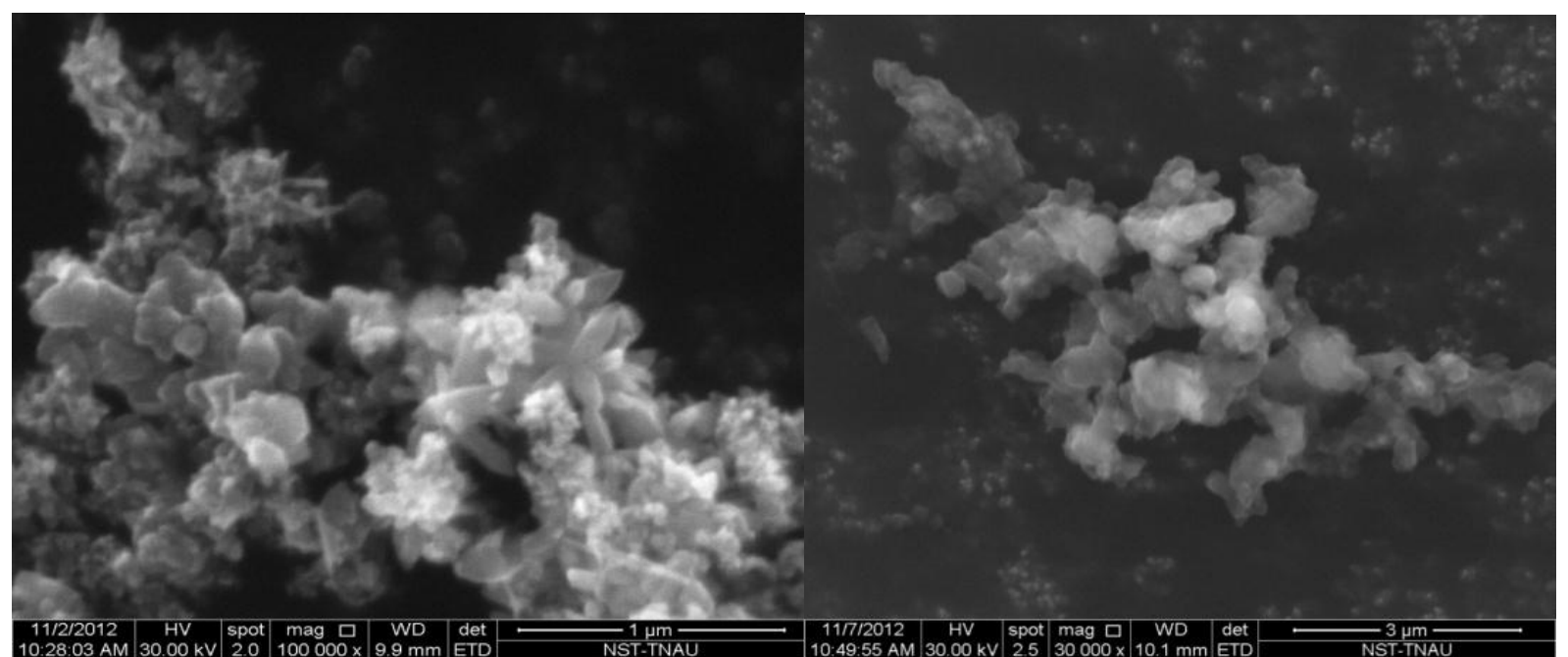

(a)

(b) 


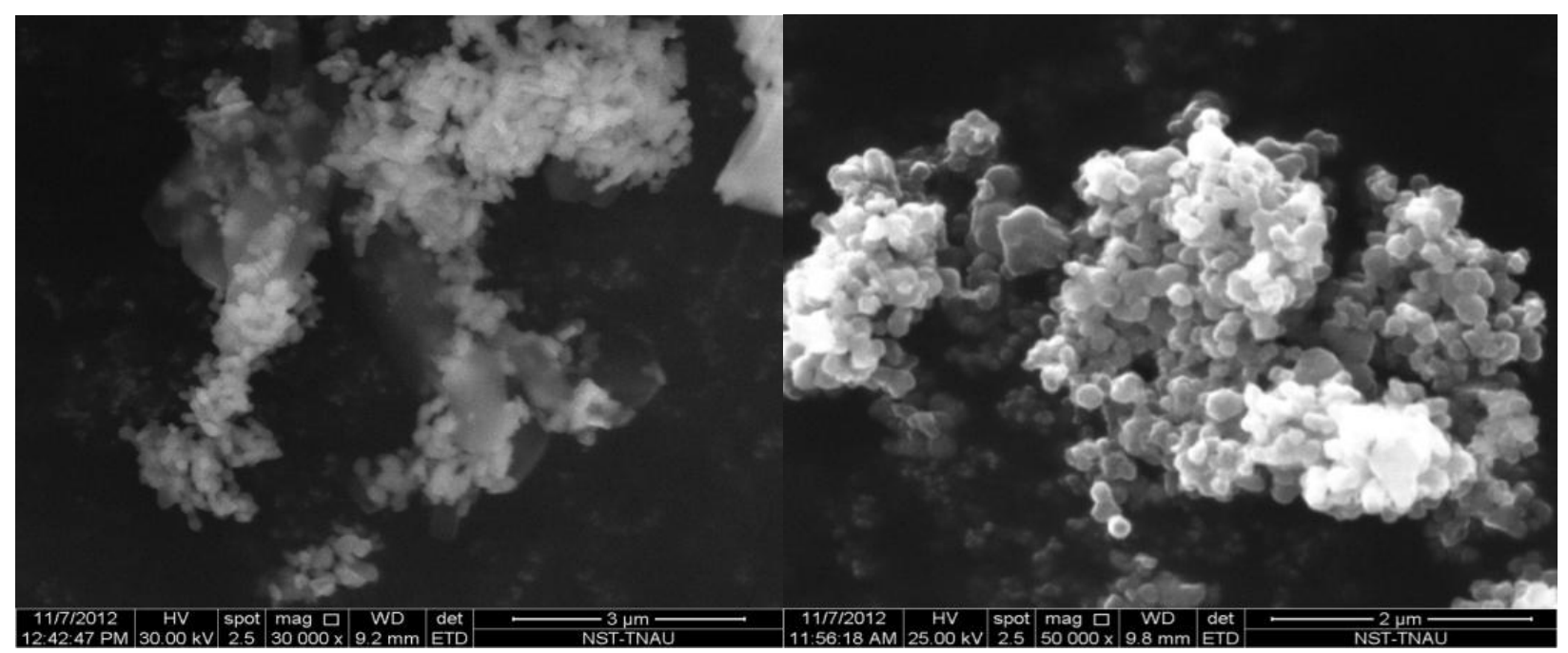

(c)

(d)

Plate.2 TEM images of (a) Zno, (b) silver, (c) $\mathrm{CuO}$ and (d) $\mathrm{TiO}_{2}$ nanoparticles

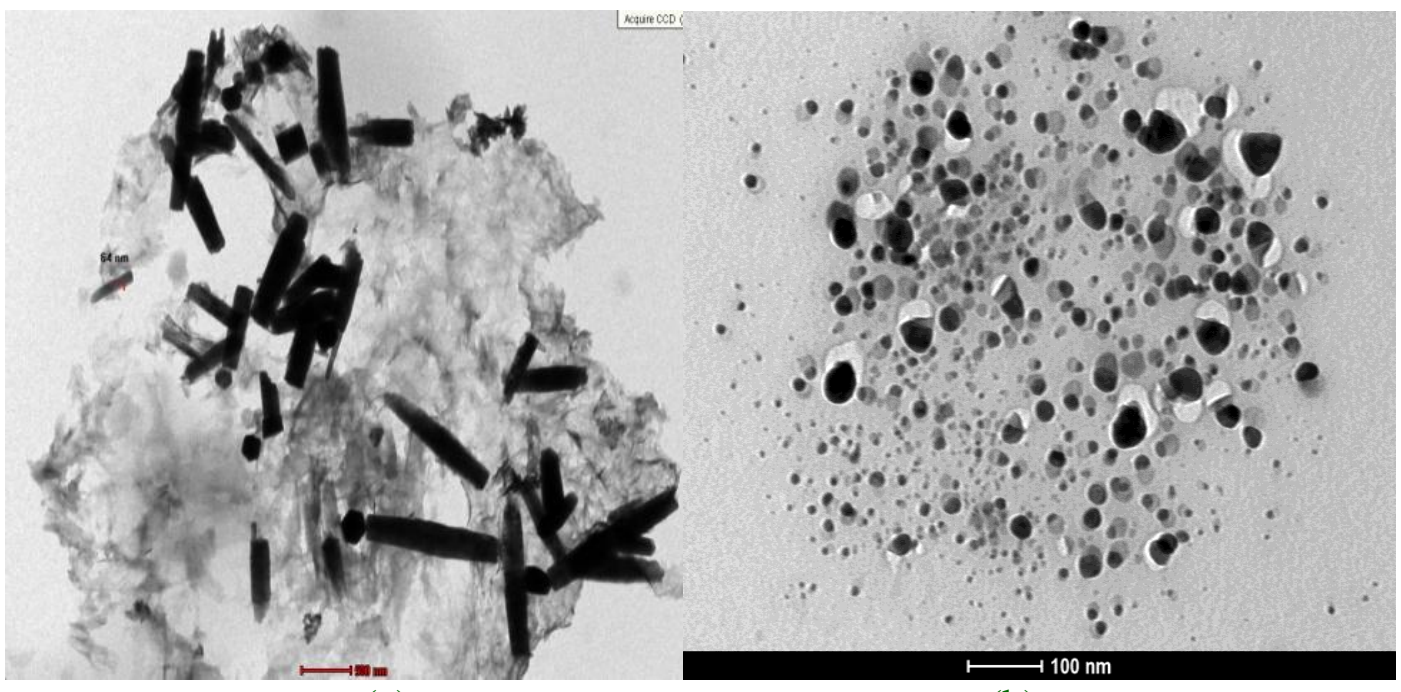

(a)

(b)

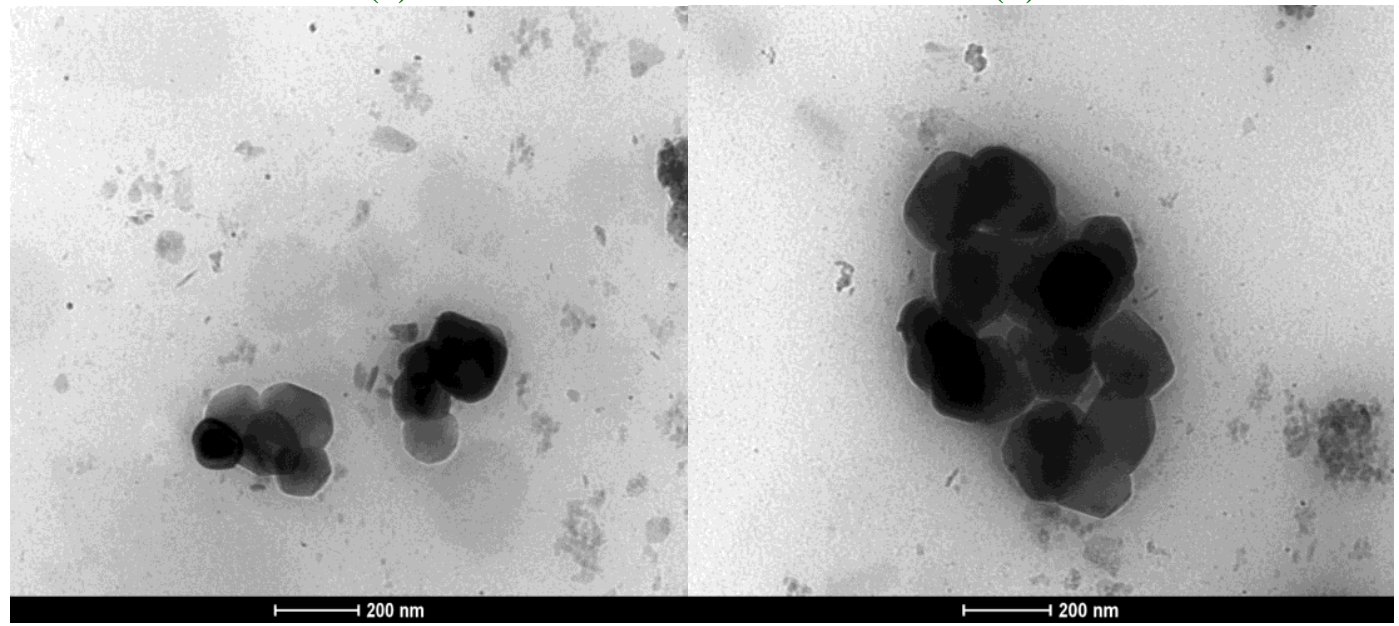

(c)

(d) 
Table.1 Effect of nanoparticles on germination \% of stored (6 months old) seeds of onion (CO 5)

\begin{tabular}{cccccc}
\hline $\begin{array}{l}\text { Treatments } \\
(\mathbf{m g} / \mathbf{k g}-1)\end{array}$ & $\mathbf{Z n O}$ & $\mathbf{A g}$ & $\mathbf{C u O}$ & $\mathbf{T i O}_{\mathbf{2}}$ & Mean \\
\hline $\mathbf{7 5 0}$ & $64(53.13)$ & $65(53.73)$ & $60(50.76)$ & $60(50.76)$ & $\mathbf{6 2}(\mathbf{5 1 . 9 4})$ \\
$\mathbf{1 0 0 0}$ & $72(58.05)$ & $69(56.18)$ & $66(54.33)$ & $65(53.73)$ & $\mathbf{6 8}(\mathbf{5 5 . 5 5})$ \\
$\mathbf{1 2 5 0}$ & $70(56.79)$ & $67(54.94)$ & $66(54.33)$ & $60(50.76)$ & $\mathbf{6 6}(\mathbf{5 4 . 3 3 )}$ \\
$\mathbf{1 5 0 0}$ & $66(54.33)$ & $66(54.33)$ & $61(51.35)$ & $62(51.94)$ & $\mathbf{6 4}(\mathbf{5 3 . 1 3})$ \\
Mean & $\mathbf{6 8}(\mathbf{5 5 . 5 5 )}$ & $\mathbf{6 7}(\mathbf{5 4 . 9 4 )}$ & $\mathbf{6 3}(\mathbf{5 2 . 5 3})$ & $\mathbf{6 2}(\mathbf{5 1 . 9 4})$ & $\mathbf{6 5}(\mathbf{5 3 . 7 3})$ \\
Control & $60(50.76)$ & $\mathbf{D}$ & $\mathbf{T D}$ & \\
\hline SEd & $\mathbf{T}$ & $\mathbf{D}$ & 0.75 & 1.68 \\
CD & $1.66^{* *}$ & $1.48^{* *}$ & $\mathrm{NS}$ & \\
\hline
\end{tabular}

Table.2 Effect of nanoparticles on shoot length $(\mathrm{cm})$ of stored (6 months old) seeds of onion (CO 5)

\begin{tabular}{|c|c|c|c|c|c|}
\hline \multirow{2}{*}{$\begin{array}{l}\text { Treatments } \\
(\mathrm{mg} / \mathrm{kg}-1)\end{array}$} & \multicolumn{5}{|c|}{ Shoot length $(\mathrm{cm})$} \\
\hline & $\mathbf{Z n O}$ & Ag & $\mathrm{CuO}$ & $\mathrm{TiO}_{2}$ & Mean \\
\hline 750 & 7.2 & 6.7 & 6.5 & 6.5 & 6.725 \\
\hline 1000 & 7.5 & 7.5 & 6.4 & 6.7 & 7.025 \\
\hline 1250 & 7.3 & 7.4 & 6.7 & 6.7 & 7.025 \\
\hline 1500 & 7.4 & 7.5 & 6.5 & 6.4 & 6.95 \\
\hline Mean & 7.3 & 7.3 & 6.5 & 6.6 & 6.925 \\
\hline \multirow[t]{2}{*}{ Control } & 6.0 & & & & \\
\hline & $\mathbf{T}$ & D & TD & & \\
\hline SEd & 0.09 & 0.08 & 0.18 & & \\
\hline CD & $0.17 * *$ & NS & NS & & \\
\hline
\end{tabular}

Table.3 Effect of nanoparticles on root length $(\mathrm{cm})$ of stored (6 months old) seeds of onion (CO 5)

\begin{tabular}{|c|c|c|c|c|c|}
\hline \multirow{2}{*}{$\begin{array}{l}\text { Treatments } \\
(\mathrm{mg} / \mathrm{kg}-1)\end{array}$} & \multicolumn{5}{|c|}{ Root length (cm) } \\
\hline & $\mathrm{ZnO}$ & Ag & $\mathrm{CuO}$ & $\mathrm{TiO}_{2}$ & Mean \\
\hline 750 & 6.2 & 5.6 & 5.2 & 5.3 & $\mathbf{5 . 5 7 5}$ \\
\hline 1000 & 6.4 & 6.3 & 5.3 & 5.4 & 5.85 \\
\hline 1250 & 6.4 & 6.2 & 5.5 & 6.4 & 6.125 \\
\hline 1500 & 6.3 & 5.8 & 5.6 & 6.3 & 6 \\
\hline Mean & 6.3 & 6.0 & 5.4 & 5.9 & 5.9 \\
\hline \multirow[t]{2}{*}{ Control } & 5.4 & & & & \\
\hline & $\mathbf{T}$ & $\mathbf{D}$ & TD & & \\
\hline SEd & 0.07 & 0.06 & 0.15 & & \\
\hline CD & $0.15^{* *}$ & $0.13 * *$ & $0.30 * *$ & & \\
\hline
\end{tabular}


Table.4 Effect of nanoparticles on vigour index of stored (6 months old) seeds of onion (CO 5)

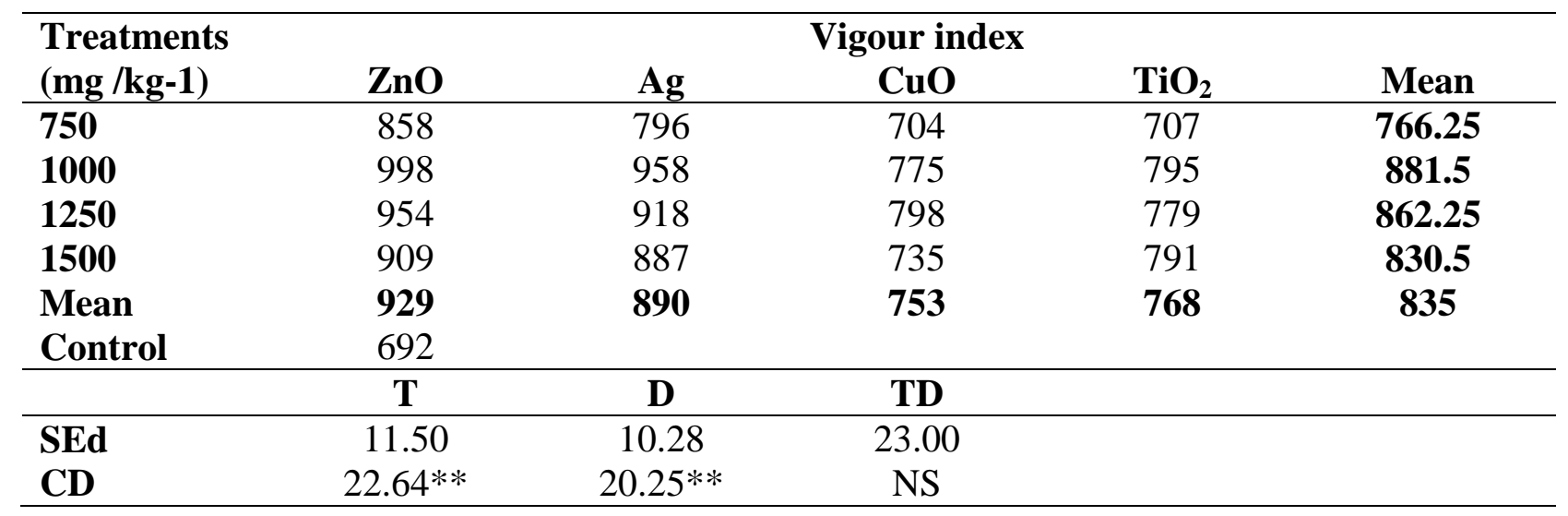

Characterization of Nanoparticles $\left(\mathrm{ZnO}, \mathrm{Ag}, \mathrm{CuO}\right.$ and $\left.\mathrm{TiO}_{2}\right)$

\begin{tabular}{|c|l|l|}
\hline \multirow{2}{*}{ Nanoparticles } & \multicolumn{1}{|c|}{ Morphological Descriptions } \\
\cline { 2 - 3 } ZnO & $\begin{array}{l}|c| \\
\text { Lanceolated nanoscaled rods measuring } \\
50-80 \mathrm{~nm} \text { diameter; appeared to be } \\
\text { radiating from a central core (Plate 1a) }\end{array}$ & $\begin{array}{l}\text { TEM } \\
\text { Rod shaped fused at centre to form a } \\
\text { radiating structure as observed in SEM } \\
\text { (Plate 2a) }\end{array}$ \\
\hline \multirow{2}{*}{$\mathbf{A g}$} & $\begin{array}{l}\text { Appeared as a bundle of spheres } \\
\text { measuring for 400-450 nm (Plate 1b) }\end{array}$ & $\begin{array}{l}\text { Spherical in shape with a size ranging } \\
\text { from 50 -100 nm (Plate 2b) }\end{array}$ \\
\hline $\mathbf{C u O}$ & $\begin{array}{l}\text { Uniform spherical to oval sized particle } \\
\text { measuring 60-150 nm (Plate 1c) }\end{array}$ & $\begin{array}{l}\text { Uniform crystalline particles } \\
\text { measuring 80-140 nm (Plate 2c) }\end{array}$ \\
\hline \multirow{2}{*}{$\mathbf{T i O}_{2}$} & $\begin{array}{l}\text { Irregular spherical shaped peanut like } \\
\text { particle with an average diameter of 120 } \\
\text { nm (Plate 1d) }\end{array}$ & $\begin{array}{l}\text { Rutile nano particle, primarily } \\
\text { tetragonal in shape with an average } \\
\text { size of 100 nm (Plate 2d). }\end{array}$ \\
\hline
\end{tabular}

The values recorded for control was 60 per cent. Among the nanoparticles treatment, seeds treated with ZnO NPs@ $1000 \mathrm{mg} \mathrm{kg}^{-1}$ had the highest germination of 72 per cent which was followed by Ag NPs @ 1000 mg $\mathrm{kg}^{-1}(69 \%)$. Control recorded the lowest germination (60\%) (Table 1). Among the dosages, seeds treated @ 1000 (72\%) found to register maximum germination than other dosages. Interaction among the NPs and dosage revealed that ZnONPs @ 1000 mg kg1and Ag NPs@ 1000 mg kg-1 recorded in the maximum germination of 72 percent while the minimum in the seed treated with $\mathrm{TiO}_{2}$ at the $750 \mathrm{mg} \mathrm{kg}^{-1}$. The beneficial effect of the $\mathrm{ZnO}$ NPs in improving the germination could be ascribed to higher precursor activity of nanoscale zinc in auxin production. Apart from this, zinc is one of the essential nutrients required for plant growth. It is an important component of various enzymes that are responsible for driving many metabolic reactions in all crops. Zinc oxide NPs are reported to also exhibit positive effect on the reactivity of phytohormones especially Indole Acetic Acid (IAA) facilitating in the phytostimulatory actions. Zinc-rich ZnO NPs could increase the level of IAA in roots (sprouts), which in turn can increase growth rate of seedlings. Enhanced physiological parameters could be attributed and quenching of free radicals by nanoparticles which could 
entered through cracks present seed coat, reached into free radicals resulting in enhanced seed vigour.

Nanoparticle treated germinated seeds exhibited higher root and shoot length than control. ZnO NPs treated seeds induced maximum shoot length $(7.5 \mathrm{~cm})$ compared to control $(6.0 \mathrm{~cm})$ after six months of storage. Among the different nano particle treatments, seeds treated with $\mathrm{ZnO}$ and Ag NPs @ 1000 $\mathrm{mg} \mathrm{kg}{ }^{-1}$ produced the lengthiest shoot length $(7.5$ and $7.5 \mathrm{~cm})$ than control $(6.0 \mathrm{~cm})($ Table 2). Nanoparticles treatment did not influence the root length of seedlings immediately after treatment. After six months of storage, nanoparticles treated seeds had higher root length $(6.4 \mathrm{~cm})$ compared to control $(5.4 \mathrm{~cm})$. Among the different nanoparticle treatments, seed treated with ZnO NPs @ 1000 and $\mathrm{Tio}_{2}$ @ $1250 \mathrm{mg} \mathrm{kg}^{-1}$ produced the lengthiest root $(6.4 \mathrm{~cm})$ than control $(5.4 \mathrm{~cm})$ (Table 3). Such promoting effect of nanoscale $\mathrm{SiO}_{2}$ and $\mathrm{TiO}_{2}$ on germination was reported in soya bean, in which authors noticed increased nitrate reductase enzyme activity and enhanced antioxidant system. Similar results were observed by (Zheng et al., 2005) when Spinacia oleracea seeds were treated with nanoscale $\mathrm{TiO}_{2}$ particles.

The results revealed the promotory effect of $\mathrm{ZnO}$ nanoparticles at optimum concentrations and inhibitory effect at high concentrations on root and shoot growth. An increase of the shoot/root ratio compared to that of the control was reported by (Shah and Belozerova, 2009) while analyzing the influence of metal nanoparticles on germination of Lactuca seeds.

Significant variation was observed for vigour index due to nano seed treatment, their dosages and their interactions (Table 4). Among the nano seed treatments, seeds treated with $\mathrm{ZnO}$ NPs resulted in maximum vigour index (998) than other treatments and the control (692). Interaction between nano seed treatment and its dosages revealed that highest vigour Index was observed in seeds treated with ZnO @ 1000 mg kg-1 (998) which

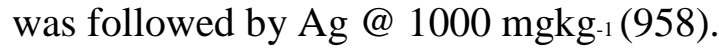

The beneficial effect of nanoparticle in improving the seed quality may be attributed that nano particles would induce oxidationreduction reactions via the superoxide ion radical during germination, resulting the quenching of free radicals in the germinating seeds. In turn, oxygen produced in such process could also be used for respiration, which would further promote germination. The experiments carried out by (Senthil kumar, 2011) revealed that black gram seeds treated with $\mathrm{ZnO}$ nano rods and ZVI NPs enhanced the physiological and biochemical properties resulting in improved vigour and viability of aged seeds. The reason attributed was the donation of electrons by the nano particles in scavenging the free radicals in the aged seeds.

Nanoparticles tested in the investigation were supportive in enhancing the germination and seedling vigour of the onion seeds which are supposed to be highly prone for deterioration in storage. Application of nanoparticles especially $\mathrm{ZnO} @ 1000 \mathrm{mg} \mathrm{kg}_{-1}$ seed improved germination and related physiological parameters. However, the findings are to be verified under large scale field condition before recommending to farmer for adoption.

\section{References}

Abdul-Baki, A.A., Anderson, J. D., 1973. Vigour deterioration of soybean seeds by multiple criteria. Crop Sci., 13:630-633.

Alocilja, E. C., and S. M. Radke., 2003. Market analysis of biosensors for food safety. Biosensors and Bielectronics., 18: 841846.

Arami, H., M. Mazloumi., R. Khalifehzadeh., and S. K. Sadmezhaad., 2007. 
Sonochemical preparation of $\mathrm{TiO}_{2}$ nanoparticles. Materials Letters., 61: 4559-4561.

Basu, R. N., 1994. An appraisal of research on wet and dry physiological seed treatments and their applicability with special reference to tropical and sub-tropical countries. Seed Sci. \& Technol., 22: 107126.

Gamiely, S., and Randle., William \& Mills., Harry \&Smittle., D.A. \& Banna., G.I., 1991. Onion Plant Growth, Bulb Quality, and Water Uptake following Ammonium and Nitrate Nutrition. HortScience: a publication of the American Society for Horticultural Science., 26.

ISTA., 2005. International Rules of Seed Testing. Seed Sci. \& Technol., 27: 27-32.

Kapri, B., A.K. Sengupta., B.K. De., A.K. Mandal., and R.N. Basu., 2003. Prestorage seed invigouration treatment for improved germinability and field performance of Okra (Hibiscus esculentus). Indian J. of Agric. Sci., 73 (5): 276-9.

Lee, P.C., Meisel, D., 2005. Adsorption and surface-enhanced raman of dyes on silver and gold sols. J Phys Chem., 86:3391-5.

Mandal, A. K., B. K. De., R. Saha., and R. N. Basu., 2000. Seed invigouration treatments for improved storability, field emergence and productivity of soybean (Glycine max L.). Seed Sci. \& Technol., 28: 349-355.

Moghaddam, A.B., Nazari, T., Badraghi, J., Kazemzad,M., 2009. Synthesis of $\mathrm{ZnO}$ Nanoparticles and Electrodeposition of Polypyrrole/ZnO Nanocomposite Film. Int J Electrochem Sci., 4:247-57.

Nair, R. S. H. Varghese., B. G. Nair., T. Maekawa., Y. Yoshida., and D.S.Kumar.,
2010.

Nanoparticulate material delivery to plants. Plant Science, 179: 154-163.

Natarajan,N., Sivasubramanian, K., 2008. Nanotechnology Application in Seed Management. Nanotechnology Applications in Agriculture., 43-52.

Senthilkumar, S., 2011. Customizing nanoparticles for the maintenance of seed vigour and viability in Blackgram (Vigna mungo) cv. VBN 4. M.Sc. Thesis, Tamil Nadu Agricultural University, Coimbatore.

Shah, V., Belozerova, I., 2009. Influence of metal nanoparticles on the soil microbial community and germination of lettuce seeds. Water, Air and Soil Pollution., 97: $143-48$.

Sridhar, C., 2012. Effect of nanoparticles for the maintenance of tomato seed vigour and viability. M.Sc. Thesis, Tamil Nadu Agricultural University, Coimbatore.

Wongpisutpaisan, Charoonsuk., Vittayakorn., and Pecharapa., 2011. Sonochemical synthesis and characterization of Copper Oxide nanoparticles. Energy procedia., 9: 6.

Zhang, F., R. Wang., Q. Xiao., Y. Wang., and J. Zhang., 2006. Effects of slow/controlledrelease fertilizer cemented and coated by nano-materials on biology. II. Effects of slow/controlled-release fertilizer cemented and coated by nano-materials on plants, Nanoscience, 11: 18-26.

Zheng, L., Hong, F., Lu, S., Liu, C., 2005. Effect of nano-TiO2 on strength of naturally aged seeds and growth of spinach. Biol Trace Elem Res., 106: 27997.

\section{How to cite this article:}

Anandaraj, K. and Natarajan, N. 2017. Effect of Nanoparticles for Seed Quality Enhancement in Onion [Allium cepa (Linn) cv. CO (On)] 5. Int.J.Curr.Microbiol.App.Sci. 6(11): 3714-3724. doi: https://doi.org/10.20546/ijcmas.2017.611.435 